\title{
Analyzing Cost Structures for Determining Possible Predatory Pricing
}

\author{
Romana Čižinská • Tomáš Krabec
}

Published online: 20 August 2014

(C) International Atlantic Economic Society 2014

\section{JEL L9}

By using a case study of a fictional corporation, Central European Railways, Plc, this paper shows the application of current analytical tests applied within the EU competition policy in order to examine and identify possible predatory pricing. Predatory prices are set in such a way that excludes rivals from competition which potentially leads to the weakening of the price mechanism and redistribution of wealth away from consumers to the dominant competitor. Therefore, predatory pricing cannot be interpreted equally with excessive prices, which only leads to enrichment of the dominant competitor at the expense of consumers.

The European Court of Justice uses a set of procedures based on a modified Areeda-Turner test (Russo et al., European Commission Decisions on Competition: Economic Perspectives on Landmark Antitrust and Merger Cases, 2011) to evaluate possible predatory pricing: the first and second AKZO test. The first AKZO test uses the criteria of marginal costs, which in practice are most often approximated by using average variable costs. The second AKZO test applies special price bands defined by average variable costs and average total costs. Prices below average total cost - which is the sum of the fixed and variable costs - but above average variable costs are regarded as abusive if there is a plan to eliminate a competitor. In addition to these economic parameters, there is an element of subjectivity which refers directly to the postulated competitive strategy of the dominant competitor.

Production at prices below average variable costs of each unit sold generates a loss totaling all fixed costs and at least a part of variable costs. It is assumed that if the dominant competitor carries out production for such prices, there is no other interest

\footnotetext{
R. Čižinská • T. Krabec $(\bowtie)$

Škoda Auto University, Na Karmeli 1457, 29301 Mladá Boleslav, Czech Republic e-mail: krabec@is.savs.cz

R. Čižinská

e-mail: cizinska@is.savs.cz
} 
except an effort to eliminate a competitor which will then allow him to raise prices by taking advantage of his monopoly position. Thus the crucial question is which costs and how they will react to changes in the volume of production and the way in which the production volume should be measured. The railway passenger traffic may not only be measured by sales volume in monetary terms but also in diverse measurement units such as the number of passengers or other industry-specific measures. By using the case study of a railway carrier, we provide a possible analytical approach of breaking down the cost structure by introducing an in-depth technical-economic analysis of the nature of costs and linking costs to their fundamental cost drivers.

For further calculations we defined variable, specific and common fixed costs as follows:

- Variable costs are those costs that would have disappeared within a year if, hypothetically, operations affected by long-distance connections in a connection from Location A to Location B were ceased.

- Specific long-term fixed costs are incremental costs that relate to a specific category of the train at a particular train connection and that within 1 year (considered in variable cost) do not vanish if the company's trains cease operations. The costs would still be in place but would be otherwise allocated.

- Common fixed costs are those for which there is no direct relationship between the amount of the costs and the scope of services. There is also no direct relationship with the operation of the trains in the particular connection.

Total costs are the sum of variable, specific fixed and common fixed costs. Costs that have been assigned to a specific category of trains at a particular connection in the context of addressing the possible abuse of a dominant position have to be classified in terms of their degree of variability. For this purpose we use the generic classification of costs in the following breakdown together with percentages of total costs which have been derived out of the controlling system of the company:

- Traction energy and fuel (16\%),

- Direct materials (3\%),

- Non-traction energy and fuel (1\%),

- Corrections from external suppliers $(8 \%)$,

- Other services $(15 \%)$,

- Wages, salaries, social security and health insurance (20\%),

- Depreciation of fixed assets (12\%),

- Other direct costs $(3 \%)$,

- Intercompany expenses (1\%),

- Payment for the use of railway infrastructure $(10 \%)$,

- Operating and administrative expenses (11\%).

From these data the values of partial variable cost drivers (VARI) can be derived by an equation to calculate variable costs (V) for monitoring the category of trains on the particular connection. Allocation of fixed costs for specific fixed and common costs were not addressed for the purpose of this case study. 